\title{
Aquatic-Derived Biomaterials for a Sustainable Future: A European Opportunity
}

\author{
Roberto Nisticò \\ Department of Applied Science and Technology DISAT, Polytechnic of Torino, C.so Duca degli Abruzzi 24, \\ 10129 Torino, Italy; roberto.nistico@polito.it; Tel.: +39-011-090-4762
}

Received: 23 September 2017; Accepted: 10 November 2017; Published: 12 November 2017

\begin{abstract}
The valorization of aquatic-derived biowastes as possible feedstock for the production of value-added chemicals and materials is proposed here as a sustainable alternative compared to the exploitation of the more conventional (fossil) resources. In this context, the comprehension of the opportunity related to the valorization of the shellfish industry biowaste for the production of useful materials, especially focusing on chitin and its derived byproducts, is investigated. The large amount of waste produced each year by the shellfish processing industry seems to be an appealing opportunity for the European market to produce valuable products from underutilized waste. In order to highlight this important market-opportunity, the actual European situation concerning the shellfish volume of production is presented. The industrial processes necessary for the recovery of chitin, chitosan, and their derivatives are largely described, together with a wide description of their peculiar (and interesting) physicochemical properties. Even if nowadays the scientific literature suggests that this class of biopolymers is very appealing, further research is still necessary for overcoming some criticisms still present in the extraction and valorization of such substrates. However, the principles of both circular economy and green chemistry encourage the reduction of such biowastes and their exploitation as an alternative resource for a global sustainable future.
\end{abstract}

Keywords: aquatic environment; biomass valorization; biopolymers; biorefinery; chitin; chitosan; shellfish waste management; sustainable materials

\section{Introduction}

Studies in the field of renewable resources have dramatically increased in the last decades due to the high economic interests in the valorization of sustainable feedstocks for obtaining useful and valuable chemicals and materials [1-6]. In general, most of the studies in this topic are involved in the valorization of agricultural and/or municipal wastes (mostly lignocellulosic- and starch-based substrates) as starting materials for the creation of new products, especially as fillers or additives in the development of both polymeric and composite materials [7-16]. This is, for instance, the case of Mater-Bi, a starch-derived commercially-available bioplastic (produced by Novamont S.p.A., Italy) [17-20]. Another opportunity is the thermal conversion of such residual substances for the production of carbon-based materials, biofuels and/or biogas [21-27]. In most cases, from bio-based substrates, it is also possible to extract fine chemicals, such as particular drugs and/or pharmaceuticals difficult to obtain by classical synthetic routes from traditional organic chemistry $[21,28,29]$. In this context, the valorization of aquatic-derived substances as possible feedstocks for the production of bio-based materials is a very attractive solution which, in those years, caught the attention of worldwide researchers and experts [1,4,30,31]. In particular, as widely-reported by Kerton et al. [1], more than $70 \%$ of our planet surface is covered by oceans and other aquatic environments, which potentially offer a wide variety of different biomasses, namely plants (mostly algae) and (in)vertebrates (i.e., basically crustacean and mollusk waste shells and other residues from fish farms). According to 
the European Union (EU), the term "biowaste" refers to biodegradable garden and park waste, food and kitchen waste from households, restaurants, caterers, and retail premises, and comparable waste from food processing plants [32]. It is important to notice that, currently, fish industries' wastes are mainly exploited as low-cost fertilizers or directly thrown into the sea, without obtaining any direct benefits. Among the different kinds of fish industry biowaste, shellfish wastes are the most interesting ones, since they are already exploited for the production of chitosan and glucosamine, two important bio-based drugs that present a very appealing market in the biomedical field due to their peculiar properties [1,33-35]. Therefore, the aim of this study is the comprehension of the opportunity related to the valorization of the shellfish industry biowaste for the production of useful materials, especially focusing on chitin and its derived byproducts.

Currently the principal environmental exploitation of biowaste by the EU is the production of methane from decomposing processes in landfills, even if this process favored the release into atmosphere of greenhouse gases [32]. In order to significantly reduce this problem, the Landfill Directive of the European Community (1999/31/EC) obliged the EU member states to reduce the amount of biodegradable municipal waste in landfills (i.e., 35\% of 1995 levels by 2016-2020). However, to ensure a significant competitive and sustainable waste management policy, the revised legislative proposal on waste by EU member states is clearly focused not only in the global reduction of waste amount, but also in promoting their re-use and recycling, in particular stimulating a symbiosis between industries (i.e., converting byproducts into raw materials) [36].

Therefore, in order to highlight this important market opportunity, an investigation of the actual European situation was provided, deepening the European market and possible future scenarios.

\section{Fish Market and Waste Management: Crustaceans, Cephalopods, and Bivalves}

Based on "The EU Fish Market" [37] published by the European Market Observatory for Fisheries and Aquaculture Products (EUMOFA), the EU production volume of fishery and aquaculture in the 2012-2014 biennium increased by 23\% (i.e., 19\% catches and $4 \%$ aquaculture). Even though the world market is due to Asian countries (74\% of the world market), the European contribution is still significant as the EU-28 total production in 2014 was of 6.2 million tons (namely, 4.9 from fisheries and 1.3 from aquaculture). Based on these data, the EU is the fifth world producer of fishery-related products (below the Asian countries: China, Indonesia, India, and Vietnam) [38]. As highlighted in the EUMOFA's document [37], the 2014 apparent consumption of fishery- and aquaculture-derived products in the EU reached almost 13 million tons, of which ca. 1 million tons of crustaceans, ca. 0.5 million tons of cephalopods, and ca. 1.4 million tons of bivalves and other aquatic invertebrates were consumed. Considering the 15 species most consumed in 2014 in the EU countries, four of them present either external shells, or radulae/beaks/cuttlebones: two of them (i.e., squids and clams) are principally fished, whereas the other two (i.e., mussels and tropical shrimps) are mainly obtained from aquaculture. On the other hand, considering the aquaculture production of bivalves (i.e., mussels, oysters, and clams) increased in 2014 reaching 609,600 tons, comprised of 475,000 tons of mussels (mainly produced in Spain), 91,500 tons of oyster (mainly produced in France), and 41,000 ton of clams (mainly produced in Italy).

According to the EUMOFA database [39], in 2016 the volume of cephalopods was ca. 898,000 tons (of which ca. 405,000 tons from Spain and ca. 194,000 tons from Italy), the bivalves volume was ca. 1 million tons (of which ca. 259,000 tons from Spain and ca. 137,000 tons from Italy), and the crustaceans volume was ca. 1.6 million tons (of which ca. 276,000 tons from Ireland and ca. 254,000 tons from Spain). By deepening the analysis of the volumes of fish industry products in the European countries, it is possible to rationalize for the different European countries forming the EU the contribution of each species for the three categories analyzed: namely, cephalopods (Table 1), bivalves (Table 1), and crustaceans (Table 2). Cephalopods are divided into four groups (i.e., cuttlefish, octopus, squid, and other cephalopods), bivalves are divided into five principal groups (i.e., clam, scallop, mussel, oyster, other mussels), whereas crustaceans are organized into nine main groups 
(i.e., European lobster, Norway lobster, red lobster, European crayfish, king/striped prawn, brown crab, common shrimp, other shrimps, and other crustaceans). Interestingly, for cephalopods results evidence that the main volumes of products involved principally Spain, Italy, and France (Table 1). The same trend is registered for the bivalves category, with some particular exceptions, such as Portugal for clams, UK for scallops, and Netherlands, Denmark, Germany and Belgium for mussels (Table 1). Concerning crustaceans, instead, the volumes are more broadly distributed among all the EU countries (not only the Mediterranean countries, but also the Northern European ones), with significant variations depending case by case (see the data reported in Table 2).

As stated in [40], it is very difficult to estimate the amount of fish-derived waste since it depends on many variables: one above all is the processing of the fished products. In general, the principal waste management options followed the well-known waste hierarchy: (i) reduce, (ii) reuse and/or recycle, and (iii) disposal. Sometimes the choice of a particular waste management option strongly depends on both the chemical composition and the mechanical properties of a datum residue. Typically, such biowastes are processed by paying a disposal cost to a third-party or specific waste management company. Depending on the kind of treatment, biowastes can be further used for other applications (e.g., composting, or incineration) [40-42]. A very interesting option is their use as starting products for the extraction of value-added chemicals. In this context, the main issue is the development of economically sustainable routes allowing the treatment of large quantities of biomasses [40]. 
Table 1. Volumes (expressed in tons) of the shellfish industry products in EU for the year 2016 obtained from the EUMOFA (European Market Observatory for Fisheries and Aquaculture products) database [39]: Cephalopods and bivalves.

\begin{tabular}{|c|c|c|c|c|c|c|c|c|c|}
\hline \multirow{2}{*}{$\begin{array}{c}\text { EU } \\
\text { Countries }\end{array}$} & \multicolumn{4}{|c|}{ Cephalopods } & \multicolumn{5}{|c|}{ Bivalves } \\
\hline & $\begin{array}{l}\text { Cuttlefish } \\
\text { (Sepia) }\end{array}$ & $\begin{array}{l}\text { Octopus } \\
\text { (Octopus) }\end{array}$ & $\begin{array}{l}\text { Squid } \\
\text { (Loligo) }\end{array}$ & $\begin{array}{c}\text { other } \\
\text { Cephalopods }\end{array}$ & $\begin{array}{c}\text { Clam } \\
\text { (Chamelea) }\end{array}$ & $\begin{array}{l}\text { Scallop } \\
\text { (Pecten) }\end{array}$ & $\begin{array}{l}\text { Mussel } \\
\text { (Mytilus) }\end{array}$ & $\begin{array}{c}\text { Oyster } \\
\text { (Ostrea) }\end{array}$ & $\begin{array}{c}\text { other } \\
\text { Mussels }\end{array}$ \\
\hline Austria & 326.50 & 252.90 & 804.10 & 459.00 & 78.10 & 140.50 & 458.10 & 125.80 & 465.00 \\
\hline Belgium & 4039.52 & 1903.04 & 6874.84 & 2141.20 & 1066.50 & 7621.05 & $24,229.30$ & 1981.80 & 3979.90 \\
\hline Bulgaria & 21.60 & 165.40 & 482.60 & 110.40 & 551.70 & 75.50 & 661.60 & 10.80 & 157.10 \\
\hline Croatia & 491.70 & 513.80 & 9403.50 & 294.40 & 65.80 & 242.80 & 263.70 & 389.40 & 4.00 \\
\hline Cyprus & 159.10 & 1049.60 & 1479.60 & 45.80 & 7.70 & 15.90 & 142.50 & 50.70 & 184.80 \\
\hline $\begin{array}{l}\text { Czech } \\
\text { Rep. }\end{array}$ & 60.00 & 274.60 & 270.30 & 81.60 & 30.00 & 66.80 & 197.40 & 79.40 & 73.20 \\
\hline Denmark & 253.40 & 821.20 & 1593.60 & 2308.03 & 739.44 & 2323.15 & $44,916.67$ & 376.34 & 8081.50 \\
\hline Estonia & 6.40 & 31.30 & 113.00 & 319.70 & 2.50 & 23.50 & 44.80 & 5.90 & 93.10 \\
\hline Finland & 8.20 & 26.50 & 66.60 & 140.50 & 6.50 & 40.20 & 170.70 & 23.00 & 81.50 \\
\hline France & $19,871.01$ & 6078.84 & $25,254.52$ & $13,563.03$ & $10,130.50$ & $33,630.63$ & $46,808.53$ & $19,034.92$ & $15,153.20$ \\
\hline Germany & 1980.60 & 3107.20 & 9078.43 & 6772.60 & 742.46 & 2430.20 & $36,001.00$ & 826.90 & 4461.90 \\
\hline Greece & 1396.70 & 7206.00 & $20,552.40$ & 530.70 & 3567.10 & 54.50 & $11,907.80$ & 148.30 & 1327.10 \\
\hline Hungary & 27.70 & 34.50 & 168.70 & 70.80 & 58.00 & 14.20 & 323.20 & 10.10 & 44.20 \\
\hline Ireland & 207.94 & 24.18 & 658.98 & 33.00 & 2626.31 & 2336.88 & $10,428.30$ & 7592.60 & 167.50 \\
\hline Italy & $24,058.39$ & $63,884.13$ & $10,1342.40$ & 4723.30 & $19,315.10$ & 8248.27 & $46,364.11$ & 6368.30 & $11,612.40$ \\
\hline Latvia & 4.70 & 54.90 & 181.90 & 151.10 & 3.20 & 27.10 & 244.60 & 67.90 & 76.80 \\
\hline Lithuania & 16.50 & 52.40 & 772.70 & 428.10 & 41.60 & 9.10 & 112.60 & 22.50 & 62.80 \\
\hline Luxembourg & 35.10 & 156.00 & 276.30 & 31.70 & 83.60 & 519.20 & 760.00 & 144.80 & 24.90 \\
\hline Malta & 61.90 & 289.10 & 374.80 & 83.80 & 77.40 & 4.80 & 120.30 & 8.50 & 100.70 \\
\hline Netherlands & 2053.70 & 1836.00 & $11,303.70$ & 647.80 & 9017.70 & 9804.00 & $79,811.50$ & 3022.20 & 5009.40 \\
\hline Poland & 66.00 & 410.20 & 337.50 & 894.40 & 183.90 & 263.70 & 340.00 & 72.20 & 433.80 \\
\hline Portugal & 6210.88 & $47,626.83$ & $35,539.20$ & 2187.90 & $23,877.50$ & 334.84 & 4789.46 & 618.53 & 3599.10 \\
\hline Romania & 106.50 & 243.40 & 452.40 & 517.10 & 41.90 & 154.60 & 255.10 & 22.50 & 136.40 \\
\hline Slovakia & 11.00 & 11.80 & 30.40 & 16.10 & 16.70 & 0.00 & 46.20 & 0.00 & 8.90 \\
\hline Slovenia & 79.20 & 417.60 & 4580.30 & 138.50 & 32.10 & 77.20 & 165.40 & 11.40 & 218.80 \\
\hline Spain & $46,058.15$ & $105,421.65$ & $232,400.60$ & $21,039.85$ & $48,100.90$ & 8772.11 & $52,654.28$ & 4996.70 & $19,424.00$ \\
\hline Sweden & 86.44 & 89.23 & 364.25 & 79.05 & 178.70 & 715.82 & 770.00 & 331.40 & 858.80 \\
\hline UK & $10,810.69$ & 1663.77 & $10,436.04$ & 2503.30 & 7419.30 & $49,297.37$ & 3911.52 & 2020.19 & 4212.90 \\
\hline EU-28 & $118,509.53$ & $243,646.07$ & $475,193.67$ & $60,312.76$ & $128,062.21$ & $127,243.91$ & $366,898.67$ & $48,363.07$ & $80,053.70$ \\
\hline
\end{tabular}


Table 2. Volumes (expressed in tons) of the shellfish industry products in the EU for the year 2016 obtained from the EUMOFA (European Market Observatory for Fisheries and Aquaculture products) database [39]: Crustaceans.

\begin{tabular}{|c|c|c|c|c|c|c|c|c|c|}
\hline \multirow{2}{*}{$\begin{array}{c}\text { EU } \\
\text { Countries }\end{array}$} & \multicolumn{9}{|c|}{ Crustaceans } \\
\hline & $\begin{array}{l}\text { European Lobster } \\
\quad \text { (Homarus) }\end{array}$ & $\begin{array}{l}\text { Norway Lobster } \\
\text { (Nephrops) }\end{array}$ & $\begin{array}{l}\text { Red Lobster } \\
\text { (Palinurus) }\end{array}$ & $\begin{array}{l}\text { European Crayfish } \\
\text { (Astacus) }\end{array}$ & $\begin{array}{l}\text { King/Striped Prawn } \\
\text { (Aristaeomorpha/Penaeus) }\end{array}$ & $\begin{array}{l}\text { Brown Crab } \\
\text { (Cancer) }\end{array}$ & $\begin{array}{c}\text { Common Shrimp } \\
\text { (Cragon) }\end{array}$ & $\begin{array}{l}\text { other } \\
\text { Shrimps }\end{array}$ & $\begin{array}{c}\text { other } \\
\text { Crustaceans }\end{array}$ \\
\hline Austria & 58.70 & 27.80 & 75.10 & 28.60 & 1528.90 & 162.10 & 425.40 & 4232.00 & 95.50 \\
\hline Belgium & 4708.83 & 1326.39 & 2476.60 & 685.80 & $43,419.20$ & 4343.36 & 4061.26 & $38,863.30$ & 1646.75 \\
\hline Bulgaria & 6.90 & 0.10 & 39.00 & 0.60 & 150.20 & 72.60 & 18.80 & 5072.20 & 3.30 \\
\hline Croatia & 21.80 & 618.90 & 110.80 & n.d. & 162.60 & 13.00 & 11.00 & 843.00 & 54.40 \\
\hline Cyprus & 20.30 & 1.80 & 11.40 & 1.10 & 938.20 & 36.40 & 0.20 & 399.60 & 9.20 \\
\hline $\begin{array}{l}\text { Czech } \\
\text { Rep. }\end{array}$ & 16.90 & 8.80 & 2.90 & 7.40 & 1177.10 & 23.80 & 10.50 & 1028.70 & 174.30 \\
\hline Denmark & 511.20 & 7906.02 & 110.20 & 8.23 & 8368.00 & 3582.66 & 3735.48 & $138,614.75$ & 6139.00 \\
\hline Finland & 33.90 & 2.20 & 57.60 & 39.50 & 267.80 & 64.50 & 26.00 & 2043.40 & 234.10 \\
\hline France & 7195.34 & $10,411.29$ & 3795.68 & 855.60 & $86,436.32$ & $21,205.36$ & 2896.47 & $32,947.31$ & 2626.93 \\
\hline Germany & 1302.10 & 492.81 & 280.40 & 302.90 & $33,181.90$ & 3042.54 & $17,310.56$ & $32,613.30$ & 1075.60 \\
\hline Greece & 160.90 & 33.10 & 206.40 & 8.30 & 2623.60 & 1046.50 & 175.70 & 6532.30 & 326.90 \\
\hline Hungary & 6.60 & 5.40 & 34.50 & 2.20 & 236.20 & 42.50 & 0.40 & 356.10 & 25.40 \\
\hline Ireland & 1074.44 & $11,167.50$ & 617.74 & 5.60 & 751.90 & $255,462.28$ & 366.53 & 4759.93 & 2047.90 \\
\hline Italy & 4481.49 & $10,223.54$ & 1242.90 & 6154.30 & $33,482.08$ & 4161.79 & 392.46 & $41,823.06$ & 2610.00 \\
\hline Latvia & 2.10 & 2.10 & 11.80 & 0.10 & 382.90 & 17.90 & 7.80 & 1740.30 & 35.70 \\
\hline Lithuania & 3.80 & 1.20 & 71.50 & 1.00 & 176.60 & 296.40 & 0.30 & 1298.70 & 46.20 \\
\hline Luxembourg & 102.20 & 48.70 & 12.10 & 14.90 & 230.70 & 79.10 & 260.50 & 925.20 & 276.90 \\
\hline Malta & 11.00 & 0.40 & 2.70 & n.d. & 162.00 & 5.40 & 0.10 & 347.30 & 7.50 \\
\hline Poland & 15.10 & 2.10 & 11.20 & 11.40 & 1865.40 & 81.20 & 617.60 & 5194.90 & 54.20 \\
\hline Portugal & 204.17 & 577.34 & 950.62 & 49.10 & $15,896.01$ & 4392.39 & 42.90 & $25,022.90$ & 1555.26 \\
\hline Romania & 15.50 & 4.50 & 7.50 & 109.50 & 487.70 & 10.40 & 2.10 & 793.00 & 3.90 \\
\hline Slovakia & 1.00 & 0.10 & 0.80 & 0.00 & 35.30 & 3.50 & 1.00 & 130.40 & 0.70 \\
\hline Slovenia & 20.50 & 168.20 & 10.60 & 6.60 & 90.40 & 4.50 & 2.30 & 453.90 & 61.70 \\
\hline Spain & 5139.42 & 7086.95 & 4249.79 & 1997.30 & $102,764.99$ & $14,562.77$ & 763.40 & $108,968.87$ & 6879.25 \\
\hline Sweden & 686.53 & 1222.40 & 355.40 & 323.60 & 1884.00 & 1156.96 & 191.80 & $30,564.16$ & 3204.70 \\
\hline UK & 8891.67 & $40,729.50$ & 1034.34 & 760.30 & $33,911.21$ & $45,273.32$ & 2367.55 & $57,478.61$ & 2183.80 \\
\hline EU-28 & $36,651.88$ & $96,018.33$ & $16,544.86$ & $11,868.93$ & $417,041.50$ & $366,044.02$ & $64,992.11$ & $609,738.89$ & $36,564.90$ \\
\hline
\end{tabular}




\section{The Chitin Industry Case Study}

Among the different chemicals and materials obtainable from the fish industry biowaste, to the best of our knowledge the main relevant (and promising) one is definitely chitin, together with chitosan (its $\mathrm{N}$-deacetylated form), and their relative monomers ( $\mathrm{N}$-acetyl)-D-glucosamine (see Figure 1 ). Chitin is the second most abundant naturally-occurring polysaccharide and it is a component of crustaceans shells, cephalopods shell parts (i.e., radulae, beaks, and cuttlebones), insect cuticles, and cell walls of some fungi [1,43-46]. Both chitin and chitosan are $\beta(1-4)$ glycans formed by 2-acetamide-2-deoxy-D-glucopyranose and 2-amino-2-deoxy-D-glucopyranose units (as shown in Figure 1), with $\left(\mathrm{C}_{6} \mathrm{H}_{10} \mathrm{O}_{4} \mathrm{~N}\right)_{n}$ as general chemical formula for this class of biopolymers $[47,48]$. The ratio between the two monomeric units corresponds to the $N$-Deacetylation Degree (or \%DD in the following), which is an indication of the molar fraction of the 2-amino-2-deoxy-D-glucopyranose units (i.e., the amount of freely-available amino groups) in the biopolymer [49].

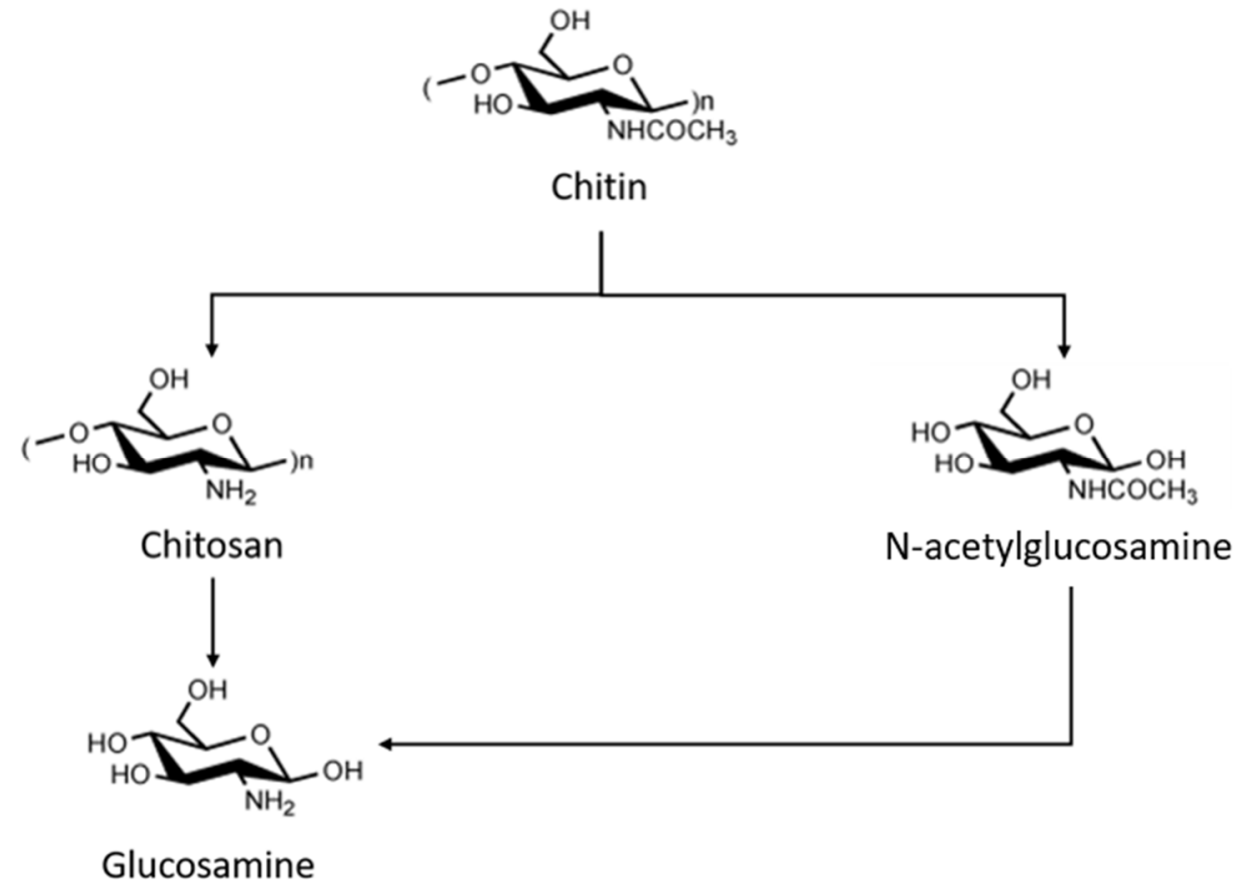

Figure 1. Chemical structures of chitin, chitosan (the $N$-deacetylated form of chitin), and their relative monomers (respectively, $\mathrm{N}$-acetylglucosamine and glucosamine).

From the chemical viewpoint, the chitin macromolecules are stabilized by $\mathrm{H}$-bonds between the polar (hydroxyl and amino) functionalities forming oriented sheet structures. Moreover, in nature chitin is present under two different crystalline forms (well distinguishable by spectroscopic and X-ray diffraction analyses): $\alpha$-chitin and $\beta$-chitin [50]. According to the literature [50], $\alpha$-chitin presents an orthorhombic crystalline structure. This phase is the most abundant crystalline form of chitin and it can be found in the cell walls of some fungi and yeasts, in the tendons and exoskeleton (shells) of crustaceans (i.e., shrimps, lobsters and crabs), and in the cuticles of insects. Apart from the naturally-occurring form, the $\alpha$-phase can be synthesized by a re-crystallization method, in vitro biosynthesis, or by direct polymerization process. Conversely, $\beta$-chitin is the less diffuse crystalline form, as it can be found associated to the proteins forming the internal gladii of cephalopods (such as squids). The crystalline structure of such $\beta$-form is monoclinic.

Curiously, such a crystalline $\beta$-form cannot be synthesized from solutions or biosynthesized in vitro, even if the $\beta$-phase is more chemically reactive than the $\alpha$-one (in fact, $\beta$-chitin can be easily converted into the more stable $\alpha$-phase by simple acid treatments) [51]. Such enhanced reactivity 
can be explained by considering the chemical structure of such biopolymers. In particular, the chitin $\mathrm{H}$-bonds due to the polar functionalities are mainly intermolecularly organized for the $\alpha$-phase, whereas, in the case of the $\beta$-phase, only intramolecular H-bonds are registered. Such an aspect strongly influences the solubility of these two allomorphs respect to polar solvents. In fact, the absence of intermolecular H-bonds explains why polar solvents (such as water, alcohols, or amines) easily penetrate the crystalline lattice of the $\beta$-phase without modifying its crystalline organization (i.e., only reversible swelling phenomena occur). Conversely, $\alpha$-chitin is not permeable to polar solvents (such as water and alcohols) due to the presence of intermolecular H-bonds between chitin chains [50]. From the practical viewpoint both crystalline forms are insoluble in water and other polar solvents, this issue is one of the main limitations in the commercial use of chitin, which requires typically more "exotic" solvents such as a mixture of $\mathrm{LiCl}$ and DMAc ( $N, N$-dimetilacetammide) [1]. In order to overcome this solubility-problem, chitin is generally converted into the more soluble chitosan (its $N$-deacetylated form), which can be dissolved into weak acid environments. The enhanced solubility of chitosan allows its use in several technological fields, such as in membranes for water softening processes [52], in water treatments as adsorbing material (alone or grafted to selected nanometric substrates) [53-56], in the agriculture industry as a protective agent against oxidation [57], as a bioplastic for food packaging [58,59], in the cosmetic industry as a moisturizing/conditioning agent [50], as carbon precursors for the development of cathodes in Li-S batteries [60], and in biomedicine as a drug delivery system and/or as hydrogels [61-63], as an antimicrobial agent/coating [34,64,65], and as technical anti-allergic textiles/sutures [66,67].

Based on the chemical composition of crustaceous shells, chitin is linked with proteins forming a chitin-protein organic matrix where minerals salts (i.e., calcium carbonate, the reinforcing component) and carotenoid pigments (mainly astaxantin and its esters) are dispersed in the shell. Once the raw crustacean shells were ground, sieved, and dried, the fractionation of the elements forming the raw materials involves three main steps (as reported in Figure 2) [1,68]. These are the deproteination (i.e., the removal of the protein), demineralization (i.e., the removal of calcium carbonate) and discoloration (i.e., the removal of the pigments). The deproteination step is a very delicate procedure since it requires chitin-protein separation, but still maintains the integrity of the amino-polysaccharide. In general, this step is the first one since it guarantees the dissolution of the chitin-protein complex, thus allowing the complete separation of chitin. Such separation is reached by means of a basic environment: typically sodium or potassium hydroxide (generally, $\mathrm{NaOH}$ at low concentration $0.125-5.0 \mathrm{M}$, at $\mathrm{T}>160{ }^{\circ} \mathrm{C}$ with contact times from minutes up to days). The main problem related to this step is that at basic $\mathrm{pH}$ chitin starts to $N$-deacetylized, thus forming chitosan (changing the \%DD). Recently, an increasing number of studies $[69,70]$ are focused on the possibility of using biological extraction for the isolation of chitin. Concerning the biological extraction, this process is obtained by means of enzymes (i.e., proteases, such as trypsin, pepsin, and/or papain) obtained from plants, microorganisms, and/or animals. One limitation of this biologically-driven extraction is the non-complete deproteination (5-10\% of residual protein), thus the chemical extraction is still the most preferred technique. Moreover, the chemical deproteination step can be realized indifferently before or after the demineralization step, whereas for the enzymatic process, it should be performed after the demineralization step. If the two processes were inverted, the minerals present in the biomass will further reduce the overall efficiency of the biologically-catalyzed separation process. 


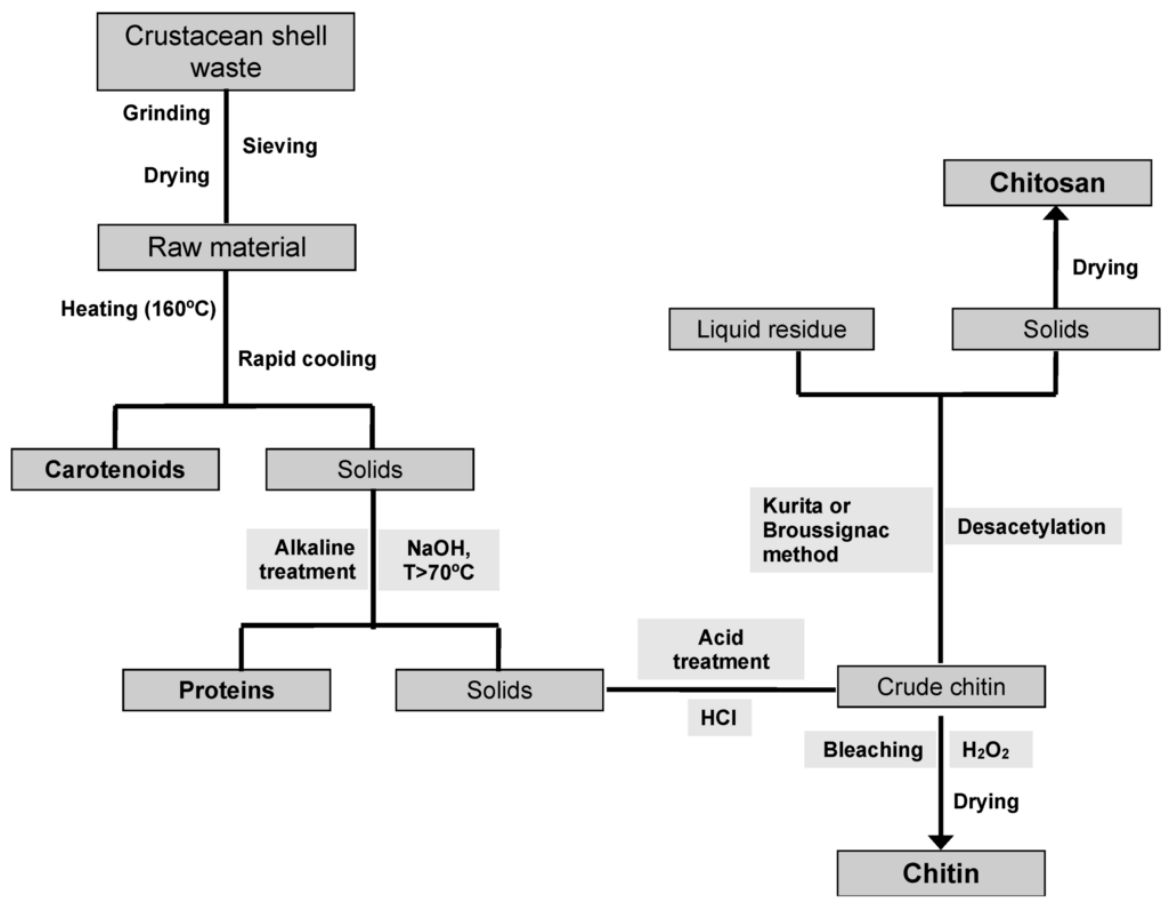

Figure 2. Schematic representation of both chitin and chitosan preparation from crustacean shell waste using traditional chemical methods. Reprinted with permission from [68].

In the demineralization step, instead, raw materials are treated in acid environments (typically strong acids such as hydrochloric, sulfuric, or nitric acids, as well as acetic acid). The most common treatment consists of using $10 \% \mathrm{HCl}$ at room temperature (RT) with a contact time of ca. $2-3 \mathrm{~h}$. This way, calcium carbonate is solubilized as $\mathrm{CaCl}_{2}$ following the reaction (1), while chitin remains as solid matrix:

$$
\mathrm{CaCO}_{3}+2 \mathrm{HCl} \rightarrow \mathrm{CaCl}_{2}+\mathrm{CO}_{2}+\mathrm{H}_{2} \mathrm{O}
$$

For the demineralization process, the experimental conditions, such as time, temperature, acid concentration, and solute/solvent ratio, strongly depend on the starting biomass (i.e., the degree of mineralization depends on the raw shells). One problem related to this step is that at acid $\mathrm{pH}$ chitin starts to hydrolyze, thus sometimes in order to minimize this side-reaction, further non-conventional treatments are preferred, such as the use of either EDTA (Ethylenediaminetetraacetic acid) or biological treatments. Lastly, in the discoloration step, the carotenoid pigments (i.e., astaxantin) linked with a macromolecular protein forming a complex named crustacyanin, should be removed by an oxidation step to produce colorless chitin. In general, this procedure is carried out by a reaction with oxidizing species, such as hydrogen peroxide or potassium permanganate. Sometimes such pigments are also recovered by means of mild heat treatments (extraction) rather than oxidation processes.

The production of chitosan, instead, starting from chitin consists in a basic treatment where the $\mathrm{N}$-deacetylation reaction takes place. Obviously, depending on the reaction chemical parameters (namely, time, temperature, and base selected) it is possible to modulate the \%DD, thus forming different chitosans with different freely-available amino groups [50]. Even for chitosan, it is possible to distinguish two different processes: a chemical deacetylation [71] and an enzymatic one [72]. Additionally, the chemical deacetylation can be carried out either in heterogeneous [73] or in homogeneous [74] conditions. Concerning the heterogeneous method, chitin is treated under a hot solution of concentrated $\mathrm{NaOH}$ for several hours, thus obtaining a water-insoluble chitosan with a $85-90 \%$ of DD. Vice versa, in the homogeneous method, chitin is firstly dissolved for $3 \mathrm{~h}$ in a concentrated $\mathrm{NaOH}$ solution and subsequently further dissolved in chopped-ice at a temperature of ca. $0{ }^{\circ} \mathrm{C}$. This way, the chitosan obtained is water-soluble with a DD minor than $45-52 \%$. The enzymatic 
process is used for the production of chitosan oligomers by exploiting hydrolytic enzymes (classified as EC. 3.5.1.41, chitin deacetylase) obtained from fungi and insects. The biopolymer thus obtained presents a very low DD, confirming that the chemical deacetylation is still the more efficient method.

\section{Chitin: A European Opportunity}

The possible exploitation of shellfish industry biowaste in Europe is a very complex issue, very difficult to analyze. As previously discussed, in Europe there are tons of fish industry-derived biomasses that, in principle, should be considered as a "Promised Land" in terms of market opportunity, since they are currently less exploited. As quantified in [75], byproducts or residues in fish and shellfish industrial processing may constitute $70 \%$ of the overall amount. Additionally, market surveys and the presence of few industrial realities suggested that the solution discussed in this manuscript is not only a potential solution, but also a real business opportunity for the EU market. From the economical viewpoint, chitin is available in the market with a price of ca. $500 € / \mathrm{kg}$, whereas chitosan's price strongly depends on the purity and the molecular weight, although it is ca. $1100-1200 € / \mathrm{kg}$. Depending on the extraction method selected (either chemical or biological), different process costs have to be taken into account (reactants and other plant costs). Obviously, a case-by-case LCA (Life Cycle Assessment) study is mandatory. Although, by considering a chitosan extraction yield of ca. $40-50 \%$ [76], the recovery of these biopolymers from such biowaste seems to be a very promising route.

Quite recently, Mo et al. [77] investigated the possible exploitation of fish waste obtained from food processing as a possible alternative to conventional ingredients for feeding aquaculture fishes. Evidence obtained confirmed that a large variety of waste materials could be used to reduce the amount of conventional protein supply in the diet of farmed fishes. This way, a real circular economy where one industry byproduct (fish waste) is converted into another industry product (fish food for aquaculture) is realized, thus confirming that the circular economy view is the direction to follow in the future. We need to completely forget the concept of "waste", and replace it with "residue". This viewpoint can also be a possible alternative economic solution in developing countries. In a recent study, Hardy et al. [78] reported the massive use of shellfish in Senegal. As evidenced by the authors, marine mollusks are abundant and easy-to-process substrates used worldwide by humans since the mid-Holocene period (see [78] and references within). As described in [79], millions of tons of shell waste are annually generated as byproducts by the Chinese shellfish industry. From the economic and sustainable viewpoint, it is desirable to convert these residues into usable products for industrial applications. Nowadays, several studies are involved in their re-use, mainly in wastewater and soil treatments $[75,79]$.

Even if the scientific literature is rich in studies focused on the possibility of producing value-added products from fish, shellfish, and crustacean processing, it is important to notice that apart from food, very few aquatic-derived products are available in the daily market. Probably, one of the main reasons for this trend is the difficulty in isolating specific parts or components, as well as obtaining specific health information (necessary for the pharmaceutical industry, see [75] and references within). In any cases, as stated before, the possibility of exploitation for obtaining value-added products strongly depends on the chemical composition of the residue: every aquatic animal category provides a different residue, with a different chemical composition, and this is also reflected on the possible extractable chemicals and materials. Lastly, another important key factor to be taken into account is that such naturally-derived substances are highly perishable and must be available in relatively large amounts on a regular basis to run the process in both an economical and sustainable way [75]. However, for the sake of comparison, it is important to highlight that several industries are growing worldwide, in particular nearby the site of production, for the production of chitin and chitosan [80]. A possible solution is the development of integrate sites where both the producers of shellfish residues and those who are involved in their valorization can collaborate in a circular economic view. One interesting example of valorization of byproducts obtained from fish industry is the case of Astro (Lavis, Italy), a fish industry located in Trentino Province (Italy) focused on trout farming. As reported in the literature, 
Fiori et al. [81] demonstrated that it is possible to produce omega-3 rich fish oils in a biorefinery concept from fish industry residues obtaining a significant benefit in terms of a reduction in utility costs and greenhouse gases emission.

Furthermore, as reported in [1], it is important to notice that both chitin and chitosan can be used as starting materials for the production of useful chemicals, such as mono-, di- and oligosaccharides via further hydrolysis processes. Some examples are the production of (i) chitobiose, a dimer of $\mathrm{N}$-acetylglucosamine (NAG) 2 , (ii) $\mathrm{N}$-acetylglucosamine (NAG) monomer, and (iii) glucosamine (GlcN) salts via enzymatically-catalyzed hydrolysis reactions of the obtained chitin/chitosan [82,83]. It is important to notice that both chitin and chitosan oligomers are molecules that possess bioactive properties (against tumors, bacteria, and fungi) that makes them suitable for the biomedical and pharmaceutical industry. In particular, since chitosan is a cationic biopolymer, it is widely studied as a carrier for the delivery of genetic materials (DNA, RNA) forming complexes by electrostatic interaction [84]. The chemistry of chitosan is strongly due to the reactivity of its amino groups, which can be used as reactive sites for the functionalization of the biopolymers with hydrophilic, hydrophobic, cationic, anionic, or specific selective moieties, thus enhancing the possibility of its use.

Jardine and co-authors [85] deeply analyzed the possibilities of exploitation of chitinous biomasses in a biorefinery. In their study, the authors reported a significant consideration concerning the valorization of chitin-containing biomasses: "countries such as China, Thailand and Ecuador have well-established aquaculture industries and hence, well established chitin and chitosan industries" [85]. Recent studies reported the possibility of the recovery of gaseous products $\left(\mathrm{NH}_{3}, \mathrm{H}_{2} \mathrm{O}, \mathrm{CO}\right.$, and $\left.\mathrm{CO}_{2}\right)$, as well as $N$-rich aromatic biochars via pyrolysis $[46,60,85,86]$. Depending on the chemical treatment employed on chitin, it is possible to obtain a platform to produce different chemicals, such as: 5-hydroxymethylfurfural (5-HMF) [87], lactic acid [88], 3-acetamido-5-acetylfuran (3A5AF) [89], levoglucosenone, acetic acid, and 4-(acetylamino)-1,3-benzenediol [86] (see Figure 3). Quite recently, levulinic acid (4-oxopentanoic acid, a keto-acid very interesting for the market since it can be used as a feedstock for the production of biofuel additives, as well as other fine chemicals) was obtained from both chitosan and glucosamine by means of a hydrolysis reaction carried out under mild conditions [90]. It is important to notice that both chitin and chitosan can also be used in composite and blended materials, opening a way to significant (and promising) future scenarios in the development of novel useful materials [91-93].

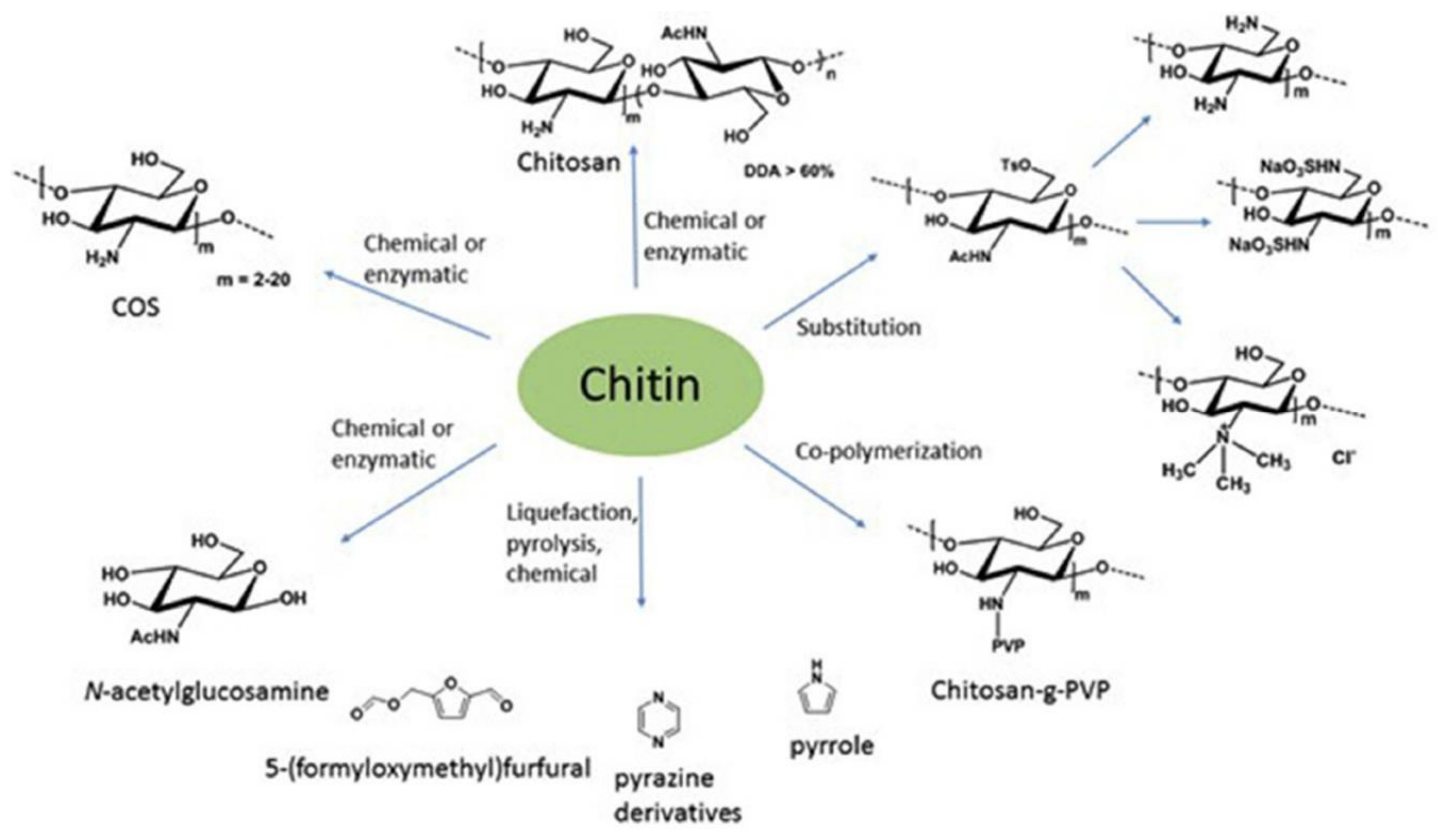

Figure 3. Chitin as potential platform for chemicals. Reprinted with permission from [85]. 


\section{Conclusions and Future Perspectives}

The environmental problems affecting our planet are largely due to human overexploitation of natural resources, including (fossil) fuels, minerals, water, land, and biodiversity. Additionally, the EU countries generate large amounts of waste. In this context, the large amount of waste produced each year by the shellfish processing industry, and the absence of sustainable (both from the economic and environmental viewpoint) waste management seem to be an appealing alternative for the European market to produce valuable products from the underutilized shellfish biowaste in substitution to the terrestrial free-lands consumption. Among the different chemicals obtainable from aquatic environments, this study is focused on the chemistry of shellfish-derived biowaste and, in particular, on the chemistry of chitin and its derived products.

Interestingly, even though $74 \%$ of the world market is basically due to Asian countries, the Europe contribution is still significant (the EU is the fifth world producer of fishery-related products). In this manuscript, we have tried to investigate from both the technical and economic viewpoint, the EU production volumes of fishery and aquaculture, analyzing the possible application of these resources in the production of usable biopolymers, namely chitin and chitosan. In this context, a methodical screening of the main processes necessary for obtaining such useful biopolymers was provided and discussed. The volume survey of EU production together with the global market prevision of chitin $(1,555,000$ metric tons by 2022) [94] encourage the exploitation of shellfish biowastes for obtaining this useful material and its derivatives. The use of chitin and chitosan themselves, or as a platform for the production of chemicals, is a great alternative to the consumption of fossil sources. Obviously, a case-by-case LCA study is mandatory, however the benefits coming from the valorization of chitin and chitosan are many.

Even if, nowadays, the scientific literature suggests that this class of biopolymers is very appealing, there are still some criticisms in the method of exploitation (i.e., high perishability of the starting biomass, difficulty of biomass fractionation, its regular supply, etc.). Further research is required to investigate a better route for overcoming the technical and engineering problems related to biowaste management in a broader sense. In this context, the policy of EU countries will surely act as a stimulating agent. In our opinion, the exploitation of the aquatic environment is a green, useful, and promising opportunity for Europe, which needs to be taken into account in order to develop both innovative and green solutions for a global sustainable future.

Acknowledgments: Polytechnic of Torino is gratefully acknowledged for funding project Starting Grant RTD (project number: 54_RSG17NIR01). Additionally, the author would like to thank F. Guerretta (University of Torino, Italy) for his precious help.

Author Contributions: R.N. conceived, designed, and wrote the paper.

Conflicts of Interest: The author declares no conflict of interest.

\section{References}

1. Kerton, F.M.; Liu, Y.; Omari, K.W.; Hawboldt, K. Green chemistry and the ocean-based biorefinery. Green Chem. 2013, 15, 860-871. [CrossRef]

2. Bozell, J.J.; Petersen, G.R. Technology development for the production of biobased products from biorefinery carbohydrates-The US Department of Energy's “Top 10" revisited. Green Chem. 2012, 12, 539-554. [CrossRef]

3. Thomsen, M.; Seghetta, M.; Mikkelsen, M.H.; Gyldenkærne, S.; Becker, T.; Caro, D.; Frederiksen, P. Comparative life cycle assessment of biowaste to resource management systems-A Danish case study. J. Clean. Prod. 2017, 142, 4050-4058. [CrossRef]

4. Lopes, C.; Antelo, L.T.; Franco-Uria, A.; Alonso, A.A.; Perez-Martin, R. Valorisation of fish by-products against waste management treatments-Comparison of environmental impacts. Waste Manag. 2015, 46, 103-112. [CrossRef] [PubMed]

5. Mao, X.; Guo, N.; Sun, J.; Xue, C. Comprehensive utilization of shrimp waste based on biotechnological methods: A review. J. Clean. Prod. 2017, 143, 814-823. [CrossRef] 
6. Ciuta, S.; Antognoni, S.; Rada, E.C.; Ragazzi, M.; Badea, A.; Cioca, L.I. Respirometric index and biogas potential of different foods and agricultural discarded biomass. Sustainability 2016, 8, 1311. [CrossRef]

7. Rivero, C.P.; Hu, Y.; Kwan, T.H.; Webb, C.; Theodoropoulos, C.; Daoud, W.; Lin, C.S.K. 1-Bioplastics from solid waste. In Current Developments in Biotechnology and Bioengineering, Solid Waste Management, 1st ed.; Wong, J.W.C., Tyagi, R.D., Pandey, A., Eds.; Elsevier: Amsterdam, The Netherlands, 2017; pp. 1-26.

8. Brockhaus, S.; Petersen, M.; Kersten, W. A crossroads for bioplastics: Exploring product developers' challenges to move beyond petroleum-based plastics. J. Clean. Prod. 2016, 127, 84-95. [CrossRef]

9. Kai, D.; Tan, M.J.; Chee, P.L.; Chua, Y.K.; Yap, Y.L.; Loh, X.J. Towards lignin-based functional materials in a sustainable world. Green Chem. 2016, 18, 1175-1200. [CrossRef]

10. Isikgor, F.H.; Remzi Becer, C. Lignocellulosic biomass: A sustainable platform for the production of bio-based chemicals and polymers. Polym. Chem. 2015, 6, 4497-4559. [CrossRef]

11. Nisticò, R.; Evon, P.; Labonne, L.; Vaca-Medina, G.; Montoneri, E.; Vaca-Garcia, C.; Negre, M. Post-harvest tomato plants and urban food wastes for manufacturing plastic films. J. Clean. Prod. 2017, 167, 68-74. [CrossRef]

12. Zia, K.M.; Noreen, A.; Zuber, M.; Tabasum, S.; Mujahid, M. Recent developments and future prospects on bio-based polyesters derived from renewable resources: A review. Int. J. Biol. Macromol. 2016, 82, 1028-1040. [CrossRef] [PubMed]

13. Dietrich, K.; Dumont, M.-J.; Del Rio, L.F.; Orsat, V. Producing PHAs in the bioeconomy-Towards a sustainable bioplastics. Sustain. Prod. Consum. 2017, 9, 58-70. [CrossRef]

14. Franzoso, F.; Vaca-Garcia, C.; Rouilly, A.; Evon, P.; Montoneri, E.; Persico, P.; Mendichi, R.; Nisticò, R.; Francavilla, M. Extruded versus solvent cast blends of poly(vinyl alcohol-co-ethylene) and biopolymers isolated from municipal biowaste. J. Appl. Polym. Sci. 2016, 133, 43009-43025. [CrossRef]

15. Nisticò, R.; Evon, P.; Labonne, L.; Vaca-Medina, G.; Montoneri, E.; Francavilla, M.; Vaca-Garcia, C.; Magnacca, G.; Franzoso, F.; Negre, M. Extruded poly(ethylene-co-vinyl alcohol) composite films containing biopolymers isolated from municipal biowaste. Chem. Sel. 2016, 1, 2354-2365. [CrossRef]

16. Wang, C.; Kelley, S.S.; Venditti, R.A. Lignin-based thermoplastic materials. ChemSusChem 2016, 9, 770-783. [CrossRef] [PubMed]

17. Bastioli, C.; Bellotti, V.; Del Giudice, L.; Gilli, G. Mater-Bi: Properties and biodegradability. J. Environ. Polym. Degrad. 1993, 1, 181-191. [CrossRef]

18. Bastioli, C. Properties and applications of Mater-Bi starch-based materials. Polym. Degrad. Stab. 1998, 59, 263-272. [CrossRef]

19. Borchani, K.E.; Carrot, C.; Jaziri, M. Biocomposites of Alfa fibers dispersed in the Mater-Bi ${ }^{\circledR}$ type bioplastic: Morphology, mechanical and thermal properties. Compos. Part A Appl. Sci. Manuf. 2015, 78, 371-379. [CrossRef]

20. Lopez, J.P.; Vilaseca, F.; Barberà, L.; Bayer, R.J.; Pelach, M.A.; Mutjé, P. Processing and properties of biodegradable composites based on Mater-Bi ${ }^{\circledR}$ and hemp core fibres. Resour. Conserv. Recycl. 2012, 59, 38-42. [CrossRef]

21. Chen, Z.; Wan, C. Biological valorization strategies for converting lignin into fuels and chemicals. Renew. Sust. Energ. Rev. 2017, 73, 610-621. [CrossRef]

22. Chen, P.; Xie, Q.; Addy, M.; Zhou, W.; Liu, Y.; Wang, Y.; Cheng, Y.; Li, K.; Ruan, R. Utilization of municipal solid and liquid wastes for bioenergy and bioproducts production. Bioresour. Technol. 2016, 215, 163-172. [CrossRef] [PubMed]

23. Dahunsi, S.O.; Oranusi, S.; Efeovbokhan, V.E. Cleaner energy for cleaner production: Modeling and optimization of biogas generation from Carica papayas (Pawpaw) fruit peels. J. Clean. Prod. 2017, 156, 19-29. [CrossRef]

24. Senghor, A.; Dioh, R.M.N.; Müller, C.; Yourn, I. Cereal crops for biogas production: A review of possible impact of elevated $\mathrm{CO}_{2}$. Renew. Sust. Energ. Rev. 2017, 71, 548-554. [CrossRef]

25. Yu, K.L.; Show, P.L.; Ong, H.C.; Ling, T.C.; Lan, J.C.-W.; Chen, W.-H.; Chang, J.-S. Microalgae from wasyewater treatment to biochar-Feedstock preparation and conversion technologies. Energ. Convers. Manag. 2017, 150, 1-13. [CrossRef]

26. Jung, S.-J.; Kim, S.-H.; Chung, I.-M. Comparison of lignin, cellulose, and hemicelluloses contents for biofuels utilization among 4 types of lignocellulosic crops. Biomass Bioenergy 2015, 83, 322-327. [CrossRef] 
27. Yahya, M.A.; Al-Qodah, Z.; Zanariah Ngah, C.W. Agricultural bio-waste materials as potential sustainable precursors used for activated carbon production: A review. Renew. Sust. Energ. Rev. 2015, 46, 218-235. [CrossRef]

28. Schmidt, L.M.; Mthembu, L.D.; Reddy, P.; Deenadayalu, N.; Kaltschmitt, M.; Smirnova, I. Levulinic acid production integrated into a sugarcane bagasse based biorefiney using thermal-enzymatic pretreatment. Ind. Crops Prod. 2017, 99, 172-178. [CrossRef]

29. Beauchet, R.; Monteul-Rivera, F.; Lavoie, J.M. Conversion of lignin to aromatic-based chemicals (L-chems) and biofuels (L-fuels). Bioresour. Technol. 2012, 121, 328-334. [CrossRef] [PubMed]

30. Chew, K.W.; Yap, J.Y.; Show, P.L.; Suan, N.H.; Juan, J.C.; Ling, T.C.; Lee, D.-J.; Chang, J.-S. Microalgae biorefinery: High value products perspectives. Bioresour. Technol. 2017, 229, 53-62. [CrossRef] [PubMed]

31. Ferraro, V.; Cruz, I.B.; Jorge, R.F.; Malcata, F.X.; Pintado, M.E.; Castro, P.M.L. Valorisation of natural extracts from marine source focused on marine by-products: A review. Food Res. Int. 2010, 43, 2221-2233. [CrossRef]

32. Biodegradable waste. Available online: http://ec.europa.eu/environment/waste/compost/index.htm (accessed on 11 October 2017).

33. Croisier, F.; Jérôme, C. Chitosan-based biomaterials for tissue engineering. Eur. Polym. J. 2013, 49, 780-792. [CrossRef]

34. Avetta, P.; Nisticò, R.; Faga, M.G.; D’Angelo, D.; Aimo Boot, E.; Lamberti, R.; Martorana, S.; Calza, P.; Fabbri, D.; Magnacca, G. Hernia-repair prosthetic devices functionalised with chitosan and ciprofloxacin coating: Controlled release and antibacterial activity. J. Mater. Chem. B 2014, 2, 5287-5294. [CrossRef]

35. Nagaoka, I.; Igarashi, M.; Hua, J.; Ju, Y.; Yomogida, S.; Sakamoto, K. Recent aspects of the anti-inflammatory actions of glucosamine. Carbohydr. Polym. 2011, 84, 825-830. [CrossRef]

36. Waste. Review of Waste policy and Legislation. Available online: http://ec.europa.eu/environment/waste/ target_review.htm (accessed on 11 October 2017).

37. European Market Observatory for Fisheries and Aquaculture Products (EUMOFA), European Union. The EU Fish Market, 2016 ed.; Directorate-General for Maritime Affairs and Fisheries of the European Commission: Brussels, Belgium, 2016; ISBN 978-92-79-69443-1. [CrossRef]

38. European Commissioner for Environment, Maritime Affairs and Fisheries, European Union. Facts and Figures on the Common Fisheries Policy, Basic Statistical Data, 2016 ed.; Publications Office of the European Union: Luxembourg City, Luxembourg, 2016; ISBN 978-92-79-60972-5. [CrossRef]

39. Eumofa.eu. Ad Hoc Queries. Available online: https://www.eumofa.eu/it/ad-hoc-queries1 (accessed on 2 May 2017).

40. Seafish.org. Crustacea Processing Waste Management. Available online: http://www.seafish.org/b2b/info. asp?p=102 (accessed on 29 April 2017).

41. O'Keefe, D.M.; Owens, J.M.; Chynoweth, D.P. Anaerobic composting of crab-picking wastes for byproduct recovery. Bioresour. Technol. 1996, 58, 265-272. [CrossRef]

42. Hu, Z.; Lane, R.; Wen, Z. Composting clam processing wastes in a laboratory scale in-vessel system. Waste Manag. 2009, 29, 180-185. [CrossRef] [PubMed]

43. Ozaki, O. Glucosamine derivatives sulfo disaccharides co-working with Klotho. J. Nutr. Food Sci. 2015, 5, 416. [CrossRef]

44. Hajji, S.; Younes, I.; Ghorbel-Bellaaj, O.; Hajji, R.; Rinaudo, M.; Nasri, M.; Jellouli, K. Structural differences between chitin and chitosan extracted from three different marine sources. Int. J. Biol. Macromol. 2014, 65, 298-306. [CrossRef] [PubMed]

45. Al Sagheer, F.A.; Al-Sughayer, M.A.; Muslim, S.; Elsabee, M.Z. Extraction and characterization of chitin and chitosan from marine sources in Arabian Gulf. Carbohydr. Polym. 2009, 77, 410-419. [CrossRef]

46. Corazzari, I.; Nisticò, R.; Turci, F.; Faga, M.G.; Franzoso, F.; Tabasso, S.; Magnacca, G. Advanced physico-chemical characterization of chitosan by means of TGA coupled on-line with FTIR and GCMS: Thermal degradation and water adsorption capacity. Polym. Degrad. Stab. 2015, 112, 1-9. [CrossRef]

47. Muzzarelli, R.A.A. Chitin, 1st ed.; Pergamon Press Ltd.: Oxford, MS, USA, 1977; ISBN 9781483159461.

48. Signini, R.; Campana-Filho, S.P. On the preparation and characterization of chitosan hydrochloride. Polym. Bull. 1999, 42, 159-166. [CrossRef]

49. Hirai, A.; Odani, H.; Nakajima, A. Determination of the degree of deacetylation of chitosan by ${ }^{1} \mathrm{H}$ NMR spectroscopy. Polym. Bull. 1991, 26, 87-94. [CrossRef]

50. Rinaudo, M. Chitin and chitosan: Properties and applications. Prog. Polym. Sci. 2006, 31, 603-632. [CrossRef] 
51. Saito, Y.; Putaux, J.-L.; Okano, T.; Gaill, F.; Chanzy, H. Structural aspects of the swelling of $\beta$-chitin in $\mathrm{HCl}$ and its conversion into $\alpha$-chitin. Macromolecules 1997, 30, 3867-3873. [CrossRef]

52. Ladet, S.; David, L.; Domard, A. Multi-membrane hydrogels. Nature 2008, 452, 76-79. [CrossRef] [PubMed]

53. Nisticò, R. Magnetic materials and water treatments for a sustainable future. Res. Chem. Intermed. 2017, 43, 6911-6949. [CrossRef]

54. Nisticò, R.; Franzoso, F.; Cesano, F.; Scarano, D.; Magnacca, G.; Parolo, M.E.; Carlos, L. Chitosan-derived iron oxide systems for magnetically guided and efficient water purification processes from polycyclic aromatic hydrocarbons. ACS Sustain. Chem. Eng. 2017, 5, 793-801. [CrossRef]

55. Wan Ngah, W.S.; Teong, L.C.; Hanafiah, M.A.K.M. Adsorption of dyes and heavy metal ions by chitosan composites: A review. Carbohydr. Polym. 2011, 83, 1446-1456. [CrossRef]

56. Nisticò, R.; Celi, L.R.; Bianco Prevot, A.; Carlos, L.; Magnacca, G.; Zanzo, E.; Martin, M. Sustainable magnet-responsive nanomaterials for the removal of arsenic from contaminated water. J. Hazard. Mater. 2018, 342, 260-269. [CrossRef] [PubMed]

57. Falcon, A.B.; Cabrera, J.C.; Costales, D.; Ramírez, M.A.; Cabrera, G.; Toledo, V.; Martinez-Tellez, M.A. The effect of size and acetylation degree of chitosan derivatives on tobacco plant protection against Phytophthora parasitica nicotianae. World J. Microbiol. Biotechnol. 2008, 24, 103-112. [CrossRef]

58. Fernandez, J.G.; Ingber, D.E. Manufacturing of large-scale functional objects using biodegradable chitosan bioplastic. Macromol. Mater. Eng. 2014, 299, 932-938. [CrossRef]

59. Fernando, L.A.T.; Poblete, M.R.S.; Ongkiko, A.G.M.; Diaz, L.J.L. Chitin extraction and synthesis of chitin-based polymer films from Philippine Blue Swimming Crab (Portunus pelagicus) shells. Procedia Chem. 2016, 19, 462-468. [CrossRef]

60. Magnacca, G.; Guerretta, F.; Vizintin, A.; Benzi, P.; Valsania, M.C.; Nisticò, R. Preparation, characterization and environmental/electrochemical energy storage testing of low-cost biochar from natural chitin obtained via pyrolysis at mild conditions. Appl. Surf. Sci. 2018, 427, 883-893. [CrossRef]

61. Bernkop-Schnürch, A.; Dünnhaupt, S. Chitosan-based drug delivery systems. Eur. J. Pharm. Biopharm. 2012, 81, 463-469. [CrossRef] [PubMed]

62. Bonfaroni, M.C.; Sandri, G.; Rossi, S.; Ferrari, F.; Caramella, C. Chitosan and its salts for mucosal and transmucosal delivery. Expert Opin. Drug Deliv. 2009, 6, 923-939. [CrossRef] [PubMed]

63. Bhattarai, N.; Gunn, J.; Zhang, M. Chitosan-based hydrogels for controlled, localized drug delivery. Adv. Drug Deliv. Rev. 2010, 62, 83-99. [CrossRef] [PubMed]

64. Nisticò, R.; Faga, M.G.; Gautier, G.; Magnacca, G.; D’Angelo, D.; Ciancio, E.; Piacenza, G.; Lamberti, R.; Martorana, S. Physico-chemical characterization of functionalized polypropylenic fibers for prosthetic applications. Appl. Surf. Sci. 2012, 258, 7889-7896. [CrossRef]

65. Elsabee, M.Z.; Abdou, E.S. Chitosan based edible films and coatings: A review. Mater. Sci. Eng. C 2013, 33, 1819-1841. [CrossRef] [PubMed]

66. Yang, Y.; Yang, S.-B.; Wang, Y.-G.; Zhang, S.-H.; Yu, Z.-F.; Tang, T.-T. Bacterial inhibition potential of quaternised chitosan-coated VICRYL absorbable suture: An in vitro and in vivo study. J. Orthop. Transl. 2017, 8, 49-61. [CrossRef]

67. Alay, E.; Duran, K.; Korlu, A. A sample of work on green manufacturing in textile industry. Sustain. Chem. Pharm. 2016, 3, 39-46. [CrossRef]

68. Vázquez, J.A.; Rodríguez-Amado, I.; Montemayor, M.I.; Fraguas, J.; del Pilar González, M.; Anxo Murado, M. Chondroitin sulfate, hyaluronic acid and chitin/chitosan production using marine waste sources: Characteristics, applications and eco-friendly processes: A review. Mar. Drugs 2013, 11, 747-774. [CrossRef] [PubMed]

69. Khanafari, A.; Marandi, R.; Sanatei, S. Recovery of chitin and chitosan from shrimp waste by chemical and microbial methods. Iran. J. Environ. Health Sci. Eng. 2008, 5, 1-24.

70. Bustos, R.O.; Healy, M.G. Microbial deproteinization of waste prawn shell. In Proceedings of the Second International Symposium on Environmental Biotechnology, Brighton, UK, 4-6 July 1994; pp. 15-25.

71. Kumari, S.; Rath, P.; Sri Hari Kumar, A.; Tiwari, T.N. Extraction and characterization of chitin and chitosan from fishery waste by chemical method. Environ. Technol. Innov. 2015, 3, 77-85. [CrossRef]

72. Kurita, K.; Sannan, T.; Iwakura, Y. Studies on chitin, 4: Evidence for formation of block and random copolymers of N-acetyl-D-glucosamine and D-glucosamine by hetero- and homogeneous hydrolyses. Makromol. Chem. 1977, 178, 3197-3202. [CrossRef] 
73. Chang, K.L.B.; Tsai, G.; Lee, J.; Fu, W.R. Heterogeneous N-deacetylation of chitin in alkaline solution. Carbohydr. Res. 1977, 303, 327-332. [CrossRef]

74. Sannan, T.; Kurita, K.; Iwakura, Y. Studies on chitin, 2. Effect of deacetylation on solubility. Makromol. Chem. 1976, 177, 3589-3600. [CrossRef]

75. Olsen, R.L.; Toppe, J.; Karunasagar, I. Challenges and realistic opportunities in the use of by-products from processing of fish and shellfish. Trends Food Sci. Technol. 2014, 36, 144-151. [CrossRef]

76. Sarbon, N.M.; Sandanamsamy, S.; Kamaruzaman, S.F.S.; Ahmad, F. Chitosan extracted from mud crab (Scylla olivicea) shells: Physicochemical and antioxidant properties. J. Food Sci. Technol. 2015, 52, 4266-4275. [CrossRef] [PubMed]

77. Mo, W.Y.; Man, Y.B.; Wong, M.H. Use of food waste, fish waste and food processing waste for China's aquaculture industry: Needs and challenge. Sci. Total Environ. 2018, 613-614, 635-643. [CrossRef] [PubMed]

78. Hardy, K.; Camara, A.; Piqué, R.; Dioh, E.; Guèye, M.; Diadhiou, H.D.; Faye, M.; Carré, M. Shellfishing and shell midden construction in the Saloum Delta, Senegal. J. Anthropol. Archaeol. 2016, 41, 19-32. [CrossRef]

79. Lu, J.; Lu, Z.; Li, X.; Xu, H.; Li, X. Recycling of shell wastes into nanosized calcium carbonate powders with different phase compositions. J. Clean. Prod. 2015, 92, 223-229. [CrossRef]

80. Rudnik, E. Compostable polymer materials: Definitions, structures, and methods of preparation. In Handbook of Biopolymers and Biodegradable Plastics: Properties, Processing and Applications; Ebnesajja, S., Ed.; Elsevier: Amsterdam, The Netherlands, 2013; pp. 213-264. ISBN 9781455728343.

81. Fiori, L.; Volpe, M.; Lucian, M.; Anesi, A.; Manfrini, M.; Guella, G. From fish waste to omega-3 concentrates in a biorefinery concept. Waste Biomass Valor. 2017, 8, 2609-2620. [CrossRef]

82. Yoon, J.H. Enzymatic synthesis of chitooligosaccharides in organic cosolvents. Enzyme Microb. Technol. 2005, 37, 663-668. [CrossRef]

83. Sashiwa, H.; Fujishima, S.; Yamano, N.; Kawasaki, N.; Nakayama, A.; Muraki, E.; Aiba, S.-I. Production of $\mathrm{N}$-acetyl-D-glucosamine from $\beta$-chitin by enzymatic hydrolysis. Chem. Lett. 2001, 31, 308-309. [CrossRef]

84. Choi, C.; Nam, J.-P.; Nah, J.-W. Application of chitosan and chitosan derivatives as biomaterials. J. Ind. Eng. Chem. 2016, 33, 1-10. [CrossRef]

85. Jardine, A.; Sayed, S. Challenges in the valorization of chitinous biomass within the biorefinery concept. Curr. Opin. Green Sustain. Chem. 2016, 2, 34-39. [CrossRef]

86. Gao, X.; Chen, X.; Zhang, J.; Guo, W.; Jin, F.; Yan, N. Transformation of chitin and waste shrimp shells into acetic acid and pyrrole. ACS Sustain. Chem. Eng. 2016, 4, 3912-3920. [CrossRef]

87. Zhang, J.; Yan, N. Formic acid-mediated liquefaction of chitin. Green Chem. 2016, 18, 5050-5058. [CrossRef]

88. Chen, X.; Chew, S.L.; Kerton, F.M.; Yan, N. Direct conversion of chitin into a N-containing furan derivative. Green Chem. 2014, 16, 2204-2212. [CrossRef]

89. Chen, X.; Liu, Y.; Kerton, F.M.; Yan, N. Conversion of chitin and N-acetyl-D-glucosamine into a N-containing furan derivative in ionic liquids. RSC Adv. 2015, 5, 20073-20080. [CrossRef]

90. Omari, K.W.; Besaw, J.E.; Kerton, F.M. Hydrolysis of chitosan to yield levulinic acid and 5-hydroxymethylfurfural in water under microwave irradiation. Green Chem. 2012, 14, 1480-1487. [CrossRef]

91. Deepthi, S.; Venatesan, J.; Kim, S.-K.; Bumgardner, J.D.; Jayakumar, R. An overview of chitin or chitosan/nano ceramic composite scaffolds for bone tissue engineering. Int. J. Biol. Macromol. 2016, 93B, 1338-1353. [CrossRef] [PubMed]

92. Liu, M.; Zheng, H.; Chen, J.; Li, S.; Huang, J.; Zhou, C. Chitosan-chitin nanocrystal composite scaffolds for tissue engineering. Carbohydr. Polym. 2016, 152, 832-840. [CrossRef]

93. Zhang, J.; Xu, W.-R.; Zhang, Y.; Li, W.; Hu, J.; Zheng, F.; Wu, Y. Liquefied chitin/polyvinyl alcohol based blend membranes: Preparation and characterization and antibacterial activity. Carbohydr. Polym. 2018, 180, 175-181. [CrossRef] [PubMed]

94. Chitin and Chitosan Derivatives Market Trends. Available online: http:/ /www.strategyr.com/MarketResearch/ Chitin_and_Chitosan_Derivatives_Market_Trends.asp (accessed on 12 October 2017).

(C) 2017 by the author. Licensee MDPI, Basel, Switzerland. This article is an open access article distributed under the terms and conditions of the Creative Commons Attribution (CC BY) license (http://creativecommons.org/licenses/by/4.0/). 